\title{
Interference between yellow starthistle and pubescent wheat- grass during grass establishment
}

\author{
T.S. PRATHER AND R.H. CALLIHAN
}

\section{Abstract}

Yellow starthistle (Centaurea solstitialis L.) and pubescent wheatgrass (Thinopyrum intermedium spp. barbulatum (Schur) Barkw. \& D.R. Dewey) were seeded and subsequently thinned to 0 , 130,260 , and 390 plants $/ \mathrm{m}^{2}$ in a factorial arrangement. Aggressivity coefficients indicated that intraspecific interference became stronger than interspecific interference, based on biomass of either pubescent wheatgrass and yellow starthistle, as the density of both species increased in a $1: 1$ ratio. Pubescent wheatgrass provided 0.5 to $\mathbf{1 . 3}$ times as much intraspecific interference, plant for plant, as the interspecific interference caused by yellow starthistle. Yellow starthistle provided from 1.5 to 4.6 times as much intraspecific interference, plant for plant, as the interspecific interference caused by pubescent wheatgrass. Weekly leaf counts showed that intraand interspecific interference from yellow starthistle was detectable 6 weeks after emergence. Weekly leaf counts showed that intraspecific interference from pubescent wheatgrass was detectable 7 weeks after emergence; interspecific interference from pubescent wheatgrass was not detectable using leaf count comparisons. Soil moisture at $\mathbf{1 0} \mathrm{cm}$ depth was correlated to leaf number of pubescent wheatgrass but not with leaf number of yellow starthistle. This may reflect the greater competitive ability of yellow starthistle.

Key Words: aggressivity, competition, Centaurea solstitialis, Thinopyrum intermedium spp. barbulatum

Yellow starthistle (Centaurea solstitialis L.) is a facultative winter annual that infests range and pasture land in the western United States. It has spread at an annual rate of 2,800 hectares per year in Idaho (Callihan et al. 1989). Desirable forage is reduced in areas dominated by yellow starthistle. In the spring, cattle and sheep may graze yellow starthistle, but after yellow starthistle bolts and produces spines, grazing animals avoid it. It is poisonous to horses, causing nigropallidal encephalomalacia (Cordy 1954). In ecological studies of yellow starthistle in Washington and Idaho, Roche (1965) concluded that light was the limited resource that kept yellow starthistle from inhabiting northernly aspects. Roche (1965) concluded light was not limiting on southernly aspects, but that yellow starthistle was limited by available moisture.

Yellow starthistle re-establishes from long-lived seed after chemical control has dissipated. Persistent seed makes yellow starthistle a difficult weed to control on rangeland using herbicides. Establishment of perennial vegetation should reduce re-establishment by yellow starthistle and provide long-term control. However, many perennial grasses are not very competitive at the seedling stage and may not survive the establishment period. A competitive, perennial grass species which can survive the establishment phase in sufficient numbers to establish a competitive perennial stand therefore is needed.

Factors affecting establishment of perennial vegetation include plant interactions such as density of plants, proportion of species, and spatial distribution of plants (Radosevich 1987). Measurement

\footnotetext{
Authors are graduate student and associate professor, Department of Plant, Soils and Entomological Sciences, University of Idaho, Moscow 83843.

Research was partially funded by ISSDA / ARS Grant 58-91 H2-9-251. Authors wish to thank Dr. B. Shaffi for assistance with statistical analyses and 2 reviewers for thei excellent suggestions.

Manuscript accepted 2 March 1991.
}

of the effects of these plant interactions has been done through: (1) additive studies, which allow quantification of the effect on plants of 1 species by increasing the density of plants of a second species (Bleasdale 1967); (2) replacement studies, which allow determination of the effect of species proportion on plants of each species while keeping total plant density constant (de Wit 1960, de Wit and van den Bergh 1965); (3) plant spacing studies, which allow determination of the effect of plant arrangement (Fischer and Miles 1973); and (4) studies combining density and proportion (Spitters 1983, Watkinson 1981).

Spitters (1983) used an addition series experiment to examine how the reciprocal yield law (Radosevich 1987) was followed in a mixture of 2 or more species. Interference between 2 species, using the reciprocal yield law, can be examined using multiple regression models of the following form:

$$
\begin{aligned}
& 1 / W_{1}=b_{1,0}+b_{1,1} N_{1}+b_{1,2} N_{2} \\
& 1 / W_{2}=b_{2,0}+b_{2,2} N_{2}+b_{2,1} N_{1}
\end{aligned}
$$

where $w_{1}$ and $w_{2}$ are the weights of plants of species 1 and $2, b_{1,0}$ and $b_{2,0}$ are the reciprocals of weights of plants of species 1 and 2 that are free from competitition, $b_{1,1}$ and $b_{2,2}$ are the regression coefficients for intraspecific interference, $b_{1,2}$ and $b_{2,1}$ are the regression coefficients for interspecific interference, and $\mathrm{N}_{1}$ and $\mathrm{N}_{2}$ are the densities of plants of species 1 and species 2, respectively.

Aggressivity is the intensity of intraspecific interference relative to interspecific interference expressed as a ratio. Aggressivity is calculated by dividing the coefficient of intraspecific interference $\left(b_{1,1}\right.$ or $\left.b_{2,2}\right)$ by the interspecific coefficient $\left(b_{1,2}\right.$ or $b_{2,1}$ ) (equations 3 or 4), yielding a number that represents the aggressivity of each species when in mixed culture:

$$
\begin{aligned}
& \text { aggressivity of species } 1\left(a_{1}\right)=b_{1,1} / b_{1,2} \\
& \text { aggressivity of species } 2\left(a_{2}\right)=b_{2,2} / b_{2,1}
\end{aligned}
$$

The goal of this study was to quantify interference of pubescent wheatgrass (Thinopyrum intermedium spp. barbulatum (Schur) Barkw. \& D.R. Dewey) and yellow starthistle when pubescent wheatgrass was at the seedling stage. The overall goal was sought through 2 specific objectives: (1) to measure the relative aggressivity of each species; and (2) to quantify interference for water as soil moisture becomes limiting.

\section{Materials and Methods}

\section{Experimental Methodology}

A loam soil ( $30 \%$ sand, $55 \%$ silt, and $15 \%$ clay; $\mathrm{pH}=6.1$ ) was ground, mixed, and placed in $192 \mathrm{~L}$ plastic containers $(56 \times 56 \times 76$ $\mathrm{cm}$ ) that were large enough to allow rooting depth differences between species (Berendse 1979, Snaydon 1979). Five or 6 seeds of either yellow starthistle or pubescent wheatgrass were sown at equidistant positions located by grids of different sizes to achieve desired plant densities. Seeds were sown equidistantly to achieve maximum intraspecific and interspecific interference (Fischer and Miles 1973). After emergence, plants were thinned to 1 plant per position. Final densities in monoculture were $0,130,260$, and 390 plants $/ \mathrm{m}^{2}$ that bracketed pubescent wheatgrass densities commonly seeded in the field (183-215 plants $\left./ \mathrm{m}^{2}\right)$, and that reached minimum early-season yellow starthistle densities (350 to 700 
Table 1. Densities and density proportions (pubescent wheatgrass/yellow starthistle) used as independent variables in the experiment.

\begin{tabular}{lcccc}
\hline \hline & \multicolumn{4}{c}{$\begin{array}{c}\text { Densities } \\
\text { (plants/m }\end{array}$} \\
\hline $\begin{array}{l}\text { Density } \\
\text { porportion }\end{array}$ & $0 / 0$ & $0 / 130$ & $0 / 260$ & $0 / 390$ \\
$\begin{array}{l}\text { Density } \\
\text { proportion }\end{array}$ & $130 / 0$ & $130 / 130$ & $130 / 260$ & $130 / 390$ \\
$\begin{array}{l}\text { Density } \\
\text { proportion }\end{array}$ & $260 / 0$ & $260 / 130$ & $260 / 260$ & $260 / 390$ \\
Density & - & $2: 1$ & $1: 1$ & $2: 3$ \\
proportion & $390 / 0$ & $390 / 130$ & $390 / 260$ & $390 / 390$ \\
\hline
\end{tabular}

plants $/ \mathrm{m}^{2}$ ). Densities in mixed culture of yellow starthistle and pubescent wheatgrass ranged from 260 to 774 plants $/ \mathrm{m}^{2}$. Density and proportion treatments are summarized in Table 1.

The plants for blocks 1 and 2 were grown from September 1986 through December 1986 and those in blocks 3 and 4 from January, 1987 through April, 1987. Growing conditions of the plants in the greenhouse consisted of 16 hours of supplemental light from metal halide lamps yielding 380 to $580 \mu \mathrm{E} \mathrm{m}^{-2} \mathrm{~s}^{-1}$ at the soil surface and an air temperature ranging from 25 to $30^{\circ} \mathrm{C}$.

Soil moisture and plant moisture were monitored using an electrical resistance block (Hillel 1980) buried $10 \mathrm{~cm}$ deep in each pot. Soil moisture was monitored each week by recording electrical resistance from the soil moisture blocks. Soil moisture was brought to nearly field capacity for the first 5 weeks after electrical resistances were recorded. Six weeks after emergence, the soil water in each pot was brought to near field capacity by using amounts of water to compensate for differences indicated by resistance readings; then the pots were not watered for the remaining 2 weeks of the experiment.

Relative water content (RWC) (Weatherley 1950, Barrs and Weatherley 1962, Milburn and Weatherley 1971) of randomly selected plants was measured weekly during the final 3 weeks of the experiment. A newly expanded yellow starthistle leaf was excised from each of these plants for RWC. To reduce photosynthetic tissue loss from plants to be used for subsequent measurements, half of the uppermost, fully expanded leaf from the main culm of pubescent wheatgrass was excised for RWC. Excised leaves were placed in plastic bags within 15 seconds after excision, the bags were pressed flat to reduce air in the bag and sealed. The bags were then placed in a dark cooler at $10^{\circ} \mathrm{C}$ until water content determination. Samples were prepared by cutting each pubescent wheatgrass leaf tissue sample into four, 5- to 7-mm segments and each yellow starthistle leaf tissue sample into three, 5- to $7-\mathrm{mm}$ segments. Samples were taken at least $1 \mathrm{~cm}$ from the cut end of the leaf to avoid tissue that lost water during the initial cutting and subsequent transport of the leaves. Each sample was weighed on an analytical balance and was placed in a 10 -ml glass vial containing $10 \mathrm{ml}$ of cold distilled water. The vials were then placed in a water bath at $4^{\circ} \mathrm{C}$ for 4 hours, after which the leaf tissue was removed from the vial, blotted dry, and reweighed. Relative water content was calculated using equation:

$$
\mathrm{RWC}=\text { Fresh tissue weight } / \text { Imbibed tissue weight. }
$$

Pubescent wheatgrass leaf and culm number and yellow starthistle leaf number were counted on a weekly basis, 2 weeks after emergence. Plant height of both species was measured on a weekly basis beginning 2 weeks after emergence. Plant height was measured to the tallest point of the plant as it was found in the canopy. Two plants of each species were selected randomly and marked in each treatment so that the same plants would be measured each week. Eight weeks after emergence all marked plants were harvested individually for aboveground biomass, dried at $35^{\circ} \mathrm{C}$ for 48 hours and weighed.

\section{Statistical Methodology}

Since growth component data were taken at weekly intervals, the design was a randomized complete block, split-plot with a factorial arrangement of density treatments, with week of sampling as the nested treatment. Only 2 blocks could be planted at 1 time because of space constraints so the experiment was blocked in time and space for a total of 4 blocks. All statistical analyses were done using the Statistical Analysis System (SAS 1985).

Biomass data were analyzed in 2 steps using stepwise regression and either least squares or generalized least squares regression. The MAXR option in the STEPWISE procedure in SAS (1985) was used to select an appropriate model using the following density variables and interaction terms: yellow starthistle density, pubescent wheatgrass density, pubescent wheatgrass/yellow starthistle or yellow starthistle/pubescent wheatgrass, pubescent wheatgrass*yellow starthistle, yellow starthistle/ (yellow starthistle+pubescent wheatgrass), pubescent wheatgrass/(pubescent wheatgrass + yellow starthistle). The model with the lowest Mallows' $C_{p}$ statistic (Myers 1986) was chosen for analysis using either least squares regression or generalized least squares regression. Heterogeneity of variance was detected in the biomass data of pubescent wheatgrass; therefore, weighted least squares regression was used in place of ordinary least squares regression as a corrective measure. The dependent variable, the reciprocal of the biomass of individual plants, was weighted using the variance at each density treatment (Spitters 1983).

Electrical resistance measurements were used as covariates in the growth component analysis of variance. The experiment was first analyzed as 2 experiments with 2 blocks each. Since the main effect of experiment as well as the interaction terms (experiment ${ }^{*}$ treatment) were not significant, the final analyses were conducted, combining all blocks into a single randomized complete block experiment. Mean separations were done using the least squares means separation technique LSMEANS with the PDIFF option in SAS (1985). The least squares means are adjusted for the covariates kept at their respective mean values. Least squares means and arithmetic means are equal when a design is balanced and there are no covariates. Correlation between RWC, density of both yellow starthistle and pubescent wheatgrass, growth components and electrical resistance readings were calculated and tested for significance using the correlation procedure CORR in SAS (1985).

\section{Results}

\section{Biomass}

Stepwise regression analysis of pubescent wheatgrass biomass data showed no significant effect of yellow starthistle density on pubescent wheatgrass biomass; however, pubescent wheatgrass density and a density interaction (yellow starthistle/ (yellow starthistle+pubescent wheatgrass)) were significant. The model containing pubescent wheatgrass and yellow starthistle/(yellow starthistle+pubescent wheatgrass) had the lowest $C_{p}$ indicating that this model was the best of all models tested. These terms were significant at $P>0.05$ as indicated by generalized least squares regression.

Pubescent wheatgrass biomass was predicted best by the equation $\left(R^{2}{ }_{\text {adj }}=0.69\right)$ :

$$
B_{1}=1 /\left(0.1637+0.0003 \mathrm{~N}_{1}+0.174 \mathrm{~N}_{2}\right)
$$

where $B_{1}$ was the per-plant biomass of pubescent wheatgrass, $N_{1}$ was the density of pubescent wheatgrass and $\mathrm{N}_{2}$ was the density of yellow starthistle expressed as a proportion of total plant density. The regression coefficient for intraspecific interference was 0.0003 
and the regression coefficient for interaction between interspecific and intraspecific interference was $\mathbf{0 . 1 7 4}$.

Since aggressivity has been defined as the effect of intraspecific interference relative to interspecific interference, plant for plant (equations 3 and 4) we expanded the definition of aggressivity used for yellow starthistle and pubescent wheatgrass to account for interaction between each species' density. Aggressivity was thus defined as the effect of intraspecific relative to interspecific interference, using equal numbers of each species over a range of densities. Table 2 shows that as the densities of both pubescent wheatgrass and yellow starthistle increases in a 1:1 ratio, intraspecific interference becomes stronger than interspecific interference.

Table 2. Effect of increasing plant density upon aggressivity of pubescent wheatgrass and yellow starthistle when grown in equal proportions.

\begin{tabular}{lcccc}
\hline \hline \multicolumn{2}{c}{ Density } & & \multicolumn{2}{c}{ Species } \\
\cline { 1 - 2 } \cline { 5 - 5 } $\begin{array}{l}\text { Pubescent } \\
\text { wheatgrass }\end{array}$ & $\begin{array}{c}\text { Yellow } \\
\text { starthistle }\end{array}$ & & $\begin{array}{c}\text { Pubescent } \\
\text { wheatgrass }\end{array}$ & $\begin{array}{c}\text { Yellow } \\
\text { starthistle }\end{array}$ \\
\hline (plants $\left./ \mathrm{m}^{2}\right)$ & & & \multicolumn{2}{c}{ (Aggressivity') } \\
130 & 130 & & 0.49 & 1.53 \\
260 & 260 & & 0.90 & 3.06 \\
390 & 390 & & 1.34 & 4.59 \\
\hline
\end{tabular}

'Aggressivity calculated using equations 3 and 4 with interference coefficients from equations 6 and 7.

At 130 plants $/ \mathrm{m}^{2}$, pubescent wheatgrass was half as competitive as yellow starthistle (aggressivity=0.49). When densities of each species increased to 260 plants $/ \mathrm{m}^{2}$, aggressivity of pubescent wheatgrass increased; i.e., intraspecific interference nearly equalled interspecific interference (aggressivity $=0.90$ ). Pubescent wheatgrass became more competitive (aggressivity $=1.34$ ) than yellow starthistle was with pubescent wheatgrass at 390 plants $/ \mathrm{m}^{2}$.

Stepwise regression analysis of yellow starthistle biomass data indicated yellow starthistle density and an interaction of density (pubescent wheatgrass/(pubescent wheatgrass+yellow starthistle)) gave the best model. Ordinary least squares regression analysis showed the density term for yellow starthistle to be significant at $P$ $>0.05$, but the interaction term was not significant $(P>0.15)$. The interaction term was included, even though a $t$-test was not significant, because the $C_{p}$ was lowest and $R^{2}$ adj was highest $\left(R^{2}{ }_{\text {adj }}=0.80\right)$ for this model in the stepwise regression analysis.

The biomass of yellow starthistle was predicted best by the equation:

$$
\mathrm{B}_{2}=1 /\left(0.1585+0.0002 \mathrm{~N}_{2}+0.0334 \mathrm{~N}_{1}\right) ;
$$

where B2 was the per-plant biomass of yellow starthistle, $\mathrm{N}_{2}$ was the density of yellow starthistle and $N_{1}$ was the density of pubescent wheatgrass expressed as a proportion of total plant density. The coefficient of intraspecific interference was 0.0002 and the coefficient of interaction between interspecific and intraspecific interference was 0.0334 .

Yellow starthistle aggressivity judged by yellow starthistle biomass was greater than pubescent wheatgrass aggressivity at all densities (Table 2). The higher aggressivity for yellow starthistle showed that intraspecific interference was greater than interspecific interference. At 130 plants $/ \mathrm{m}^{2}$, yellow starthistle was 1.5 times as aggressive as pubescent wheatgrass. Yellow starthistle became even more aggressive as density increased, and was 4.59 times as aggressive with itself as pubescent wheatgrass was with yellow starthistle plants at 390 plants $/ \mathrm{m}^{2}$.

Leaf count data were the best indicators of interference, consequently only analyses of leaf count data are presented. Analysis of leaf counts through time indicated density effects increased as the plants became larger. Intra- and interspecific interference from
Table 3. Yellow starthistle density effects on leaves of pubescent wheatgrass, averaged across pubescent wheatgrass densities, and yellow starthistle, 6 weeks after emergence.

Leaves counted'

\begin{tabular}{|c|c|c|}
\hline $\begin{array}{c}\text { Yellow } \\
\text { starthistle } \\
\text { density }\end{array}$ & $\begin{array}{l}\text { Pubescent } \\
\text { wheatgrass }\end{array}$ & $\begin{array}{l}\text { Yellow } \\
\text { starthistle }\end{array}$ \\
\hline (plants $\left./ \mathrm{m}^{2}\right)$ & \multicolumn{2}{|c|}{$\ldots \ldots \ldots$ (No./plant) $\ldots \ldots \ldots$} \\
\hline 0 & $8 \mathrm{a}$ & - \\
\hline 130 & $7 \mathrm{~b}$ & $13 \mathrm{a}$ \\
\hline 260 & $6 \mathrm{~b}$ & $12 \mathrm{ab}$ \\
\hline 390 & $6 \mathrm{~b}$ & $11 \mathrm{~b}$ \\
\hline
\end{tabular}

'Numbers in columns followed by different letters are significantly different $(P=0.05)$.

yellow starthistle began 6 weeks after emergence (Table 3). The decreases in leaf number of pubescent wheatgrass due to yellow starthistle densities did not differ statistically. Yellow starthistle leaf production at 390 yellow starthistle plants $/ \mathrm{m}^{2}$ was $90 \%$ of the leaf production at 130 yellow starthistle plants $/ \mathrm{m}^{2}$.

Seven weeks after emergence, pubescent wheatgrass leaf number decreased as the density of both pubescent wheatgrass and yellow starthistle increased (Table 4). At 130 pubescent wheatgrass plants $/ \mathrm{m}^{2}$, yellow starthistle density did not decrease pubescent wheatgrass leaf number. At 260 pubescent wheatgrass plants $/ \mathrm{m}^{2}$, all yellow starthistle densities decreased pubescent wheatgrass leaf number to at least $60 \%$ of the average monoculture leaf number;

Table 4. The interaction-density effects of pubescent wheatgrass and yellow starthistle on pubescent wheatgrass leaf production, 7 weeks after emergence.

\begin{tabular}{|c|c|c|}
\hline \multicolumn{2}{|c|}{ Plant density } & \multirow[b]{2}{*}{$\begin{array}{c}\text { Pubescent }{ }^{1} \\
\text { wheatgrass } \\
\text { leaves }\end{array}$} \\
\hline $\begin{array}{l}\text { Pubescent } \\
\text { wheatgrass }\end{array}$ & $\begin{array}{l}\text { Yellow } \\
\text { starthistle }\end{array}$ & \\
\hline \multicolumn{2}{|c|}{$\ldots \ldots \ldots \ldots$ (plants $\left./ m^{2}\right) \ldots \ldots \ldots$} & (No./plant) \\
\hline 130 & 0 & 8 bcd \\
\hline 130 & 130 & $10 \mathrm{ab}$ \\
\hline 130 & 260 & 6 def \\
\hline 130 & 390 & 6 def \\
\hline 260 & 0 & $13 \mathrm{a}$ \\
\hline 260 & 130 & $5 \mathrm{ef}$ \\
\hline 260 & 260 & 8 bcde \\
\hline 260 & 390 & 7 cdef \\
\hline 390 & 0 & 9 bc \\
\hline 390 & 130 & 7 cdef \\
\hline 390 & 260 & 8 bcde \\
\hline 390 & 390 & $4 \mathrm{f}$ \\
\hline
\end{tabular}

'Numbers in columns followed by different letters are significantly different $(P=0.05)$.

effects among yellow starthistle densities did not statistically differ. However, with 390 pubescent wheatgrass plants $/ \mathrm{m}^{2}$, only 390 yellow starthistle plants $/ \mathrm{m}^{2}$ limited pubescent wheatgrass leaf number, which was $45 \%$ of the average leaf number on plants with no competing yellow starthistle. These data indicate pubescent wheatgrass intraspecific interference began 1 week later than interspecific interference from yellow starthistle. Yellow starthistle leaf

Table 5. Yellow starthistle density effects, averaged over pubescent wheatgrass densities on yellow starthistle leaves, 7 weeks after emergence.

\begin{tabular}{lc}
\hline \hline Plant density & Leaves 1 \\
\hline (plants $\left./ \mathrm{m}^{2}\right)$ & (No./plant) \\
130 & $20 \mathrm{a}$ \\
260 & $15 \mathrm{~b}$ \\
390 & $12 \mathrm{~b}$ \\
\hline
\end{tabular}

'Numbers in columns followed by different letters are significantly different $(P=0.05)$. 
Table 6. Yellow starthistle density effects on leaf production of both pubescent wheatgrass and yellow starthistle, 8 weeks after emergence.

\begin{tabular}{lcc}
\hline & \multicolumn{2}{c}{ Leaves counted } \\
\cline { 2 - 3 } $\begin{array}{c}\text { Yellow } \\
\text { starthistle } \\
\text { density }\end{array}$ & $\begin{array}{c}\text { Pubescent } \\
\text { wheatgrass }\end{array}$ & $\begin{array}{c}\text { Yellow } \\
\text { starthistle }\end{array}$ \\
\hline (plants $\left./ \mathrm{m}^{2}\right)$ & $15 \mathrm{a}$ & - \\
0 & $8 \mathrm{~b}$ & $20 \mathrm{a}$ \\
130 & $7 \mathrm{~b}$ & $15 \mathrm{ab}$ \\
260 & $4 \mathrm{~b}$ & $12 \mathrm{~b}$ \\
390 & &
\end{tabular}

INumbers in columns followed by different letters are significantly different $(P=0.05)$.

number was reduced at 260 and 390 yellow starthistle plants $/ \mathrm{m}^{2}$ to $75 \%$ and $60 \%$ respectively of the leaf number at 130 yellow starthistle plants $/ \mathrm{m}^{2}$ (Table 5).

Pubescent wheatgrass leaf number was decreased as the density of either species increased (Tables 6 and 7), 8 weeks after emergence. Pubescent wheatgrass leaf number was lowest when in mixture with 390 yellow starthistle plants $/ \mathrm{m}^{2}$, about $30 \%$ of the average leaf number on plants with no competing yellow starthistle. At 390 plants $/ \mathrm{m}^{2}$ of pubescent wheatgrass, intraspecific interference resulted in leaf numbers below lower densities (Table 7).

Table 7. Pubescent wheatgrass density effects on pubescent wheatgrass leaf number, 8 weeks after emergence.

\begin{tabular}{lc}
\hline \hline $\begin{array}{c}\text { Plant } \\
\text { density }\end{array}$ & Leaves ${ }^{1}$ \\
\hline (plants $\left./ \mathrm{m}^{2}\right)$ & (No./plant) \\
130 & $8 \mathrm{a}$ \\
260 & $9 \mathrm{a}$ \\
390 & $7 \mathrm{~b}$ \\
\hline
\end{tabular}

'Numbers in columns followed by different letters are significantly different $(P=0.05)$.

These data indicate that interspecific interference was more intense for pubescent wheatgrass than intraspecific interference. Yellow starthistle leaf number was not affected by pubescent wheatgrass density (data not shown). However, at 390 yellow starthistle plants $/ \mathrm{m}^{2}$, yellow starthistle leaf number was $60 \%$ of the leaf number at 130 plants $/ \mathrm{m}^{2}$ (Table 6). It appears yellow starthistle was subjected to more intense intraspecific interference than interspecific interference. Yellow starthistle growth had peaked at 7 weeks after emergence, while pubescent wheatgrass continued to produce new leaves until the conclusion of the experiment.

\section{Water}

Soil water measurements at $10 \mathrm{~cm}$ were not the complete criteria of competition for water. These measurements should provide more suitable criteria for pubescent wheatgrass growth than for yellow starthistle because pubescent wheatgrass has a shallower rooting depth. Soil water measurements at $10 \mathrm{~cm}$ indicated that soil moisture was equally correlated $(r=-0.4)$ to relative water content of both pubescent wheatgrass and yellow starthistle (Table 8). There was no correlation, however, between RWC and leaf number of either species. This association indicated there was dependence of both species for water from this depth. Soil moisture at $10 \mathrm{~cm}$ was negatively correlated to leaf number of pubescent wheatgrass but no correlation with soil moisture at $10 \mathrm{~cm}$ was found for leaf number of yellow starthistle (Table 8). Lack of significant correlation between soil moisture and leaf production of yellow starthistle was speculated to be a reflection of its deeper tap-root system (Table 8).
Table 8. Pearson correlations of relative water content (RWC), soil moisture (SM) with pubescent wheatgrass and yellow starthistle leaf number and plant density.

\begin{tabular}{|c|c|c|c|c|c|c|}
\hline & \multicolumn{2}{|c|}{ Density } & \multicolumn{2}{|c|}{ Leaves } & \multicolumn{2}{|c|}{ RWC } \\
\hline & $\begin{array}{l}\text { Pubescent } \\
\text { wheat- } \\
\text { grass }\end{array}$ & $\begin{array}{c}\text { Yellow } \\
\text { star- } \\
\text { thistle }\end{array}$ & $\begin{array}{l}\text { Pubescent } \\
\text { wheat- } \\
\text { grass }\end{array}$ & $\begin{array}{c}\text { Yellow } \\
\text { star- } \\
\text { thistle }\end{array}$ & $\begin{array}{c}\text { Pubescent } \\
\text { wheat- } \\
\text { grass }\end{array}$ & $\begin{array}{c}\text { Yellow } \\
\text { star- } \\
\text { thistle }\end{array}$ \\
\hline $\begin{array}{l}\text { RWC } \\
\text { SM }\end{array}$ & $\begin{array}{r}-0.09 \\
0.01\end{array}$ & $\begin{array}{c}-0.04 \\
0.18^{*}\end{array}$ & $\begin{array}{l}-0.13 \\
-0.22^{*}\end{array}$ & $\begin{array}{r}0.07 \\
-0.07\end{array}$ & $\begin{array}{c}1.00 \\
-0.40^{*}\end{array}$ & $\begin{array}{c}1.00 \\
-0.41^{*}\end{array}$ \\
\hline
\end{tabular}

*Correlation coefficients followed by an asterisk are significant at $P=0.05$.

\section{Discussion}

Aggressivity of either yellow starthistle or pubescent wheatgrass was density dependent. Intraspecific interference by both yellow starthistle and pubescent wheatgrass became stronger than interspecific interference as density of both species increased. Interference with yellow starthistle growth was dominated by the intraspecific component whenever densities of the 2 species were equal, indicating that yellow starthistle would not be excluded by seedlings of pubescent wheatgrass. Interference with pubescent wheatgrass growth was dominated by intraspecific effects when the densities of pubescent wheatgrass and yellow starthistle were equal when the population density of each species was about 290 plants $/ \mathrm{m}^{2}$ (equation 5 ).

Yellow starthistle was the better competitor in this experiment and was subjected to more intense intraspecific effects than interspecific effects at all densities. These results support Aarssen's (1983) hypothesis which states that the superior competitor is affected more by intraspecific interference than it is by interspecific interference. In addition, the weaker competitor is affected more by interspecific interactions than by intraspecific interactions.

At seeding densities of pubescent wheatgrass normally used on rangeland (about 200 plants $/ \mathrm{m}^{2}$ ), the effects of interspecific interference are expected to be greater than intraspecific effects on pubescent wheatgrass growth. Yellow starthistle control during establishment of pubescent wheatgrass would be needed for optimal pubescent wheatgrass establishment; however, a substantial increase in pubescent wheatgrass seeding rates also may enhance its establishment by increasing its aggressivity. This experiment utilized equidistant plant spacing that maximized the competitiveness of each species. Increasing the seeding rate of pubescent wheatgrass above 200 plants $/ \mathrm{m}^{2}$ without decreasing row spacing would likely not have beneficial effects on pubescent wheatgrass establishment, as indicated by the research of Fischer and Miles (1973) and would likely increase the deleterious effects of intraspecific interference upon pubescent wheatgrass plants.

Yellow starthistle may continue to grow after conditions become dry when pubescent wheatgrass cannot draw water from soil depths as low as are accessible to yellow $\times$ starthistle seedlings. Continued yellow starthistle growth would allow yellow starthistle to be more aggressive than pubescent wheatgrass for other limited resources, i.e., light and nutrients.

Will yellow starthistle competitively exclude pubescent wheatgrass? Aarssen (1989) stated that greater longevity of a species may confer a greater ability to deny resources to offspring of the shorter-lived competitor. Pubescent wheatgrass has greater longevity and, after becoming well established, may be able to deny resources to yellow starthistle seedlings, ensuring it is not excluded from the site. Further research is needed in this area to assess the aggressivity to mature pubescent wheatgrass plants against yellow starthistle. 


\section{Literature Cited}

Aarssen, L.W. 1983. Ecological combining ability and competitive combining ability in plants: Toward a general evolutionary theory of coexistence in systems of competition. Amer. Natur. 122:707-731.

Aarssen, L.W. 1989. Competitive ability and species coexistence: a 'plant'seye' view. Oikos 56:386-401.

Barrs, H.D., and P.E. Weatherley. 1962. A re-examination of the relative turgidity technique for estimating water deficits in leaves. Aust. J. Biol. Sci. 15:412-428.

Berendse, F. 1979. Competition between plant populations with different rooting depths. Oecologia, 48:19-26.

Bleasdale, J.K.A. 1967. The relationship between the weight of a plant part and total weight as affected by plant density. J. Hortic. Sci. 42:51-58.

Callihan, R.H., F.E. Northam, J.B. Johnson, E.L. Michalson, and T.S. Prather. 1989. Yellow starthistle control. Univ. of Idaho, College of Agr., CIS 634.

Cordy, D.R. 1954. Nigropallidal encephalomalcia in horses associated with ingestion of yellow starthistle. J. Neuropathology and Exp. Neurology 13:330-342.

Fischer, R.A., and R.E. Miles. 1973. The role of spatial pattern in the competition between crop plants and weeds. Math. Biosci. 18:335-350. Hillel, D. 1980. Fundamentals of Soil Physics. Academic Press. p. 126-128.
Milburn, J.A., and P.E. Weatherly. 1971. The influence of temperature on the process of water uptake by detached leaves and leaf discs. New Phytol. 70:929-938.

Myers, R.H. 1986. Classical and modern regression with applications. PWS Publishers, Boston, Mass.

Radosevich, S.R. 1987. Methods to study interactions among crops and weeds. Weed Tech. 1:190-198.

Roche, B.F.1965. Ecologic studies of yellow starthistle (Centaurea solstitialis L.). Ph.D. Thesis, Univ. Idaho.

SAS Institute Inc., 1985. SAS user's guide: Statistics. SAS Institute Inc., Cary, N.C.

Snaydon, R.W, 1979. A new technique for studying plant interactions. J, Appl. Ecology 16:281-286.

Spitters, C.J.T. 1983. An alternative approach to the analysis of mixed cropping experiments. 1. Estimation of competition effects. Neth. J. Agr. Sci. 31:1-11.

Watkinson, A.R. 1981. Interference in pure and mixed populations of Agrostemma githago. J. Appl. Ecology 18:967-976.

Weatherley, P.E. 1950. Studies in the water relations of the cotton plant. 1 . The field measurements of water deficits in leaves. New Phytol. 49:81-97.

Wit, C.T. de 1960. On competition. Agr. Res. Rep. 66.8.

Wit, C.T. de, and J.P, van den Bergh. 1965. Competition between herbage p' nis. Neth J. A r Sij 13:?12-2?1 